\title{
Myasthenia Gravis and Diabetes Mellitus: -A 35-year Retrospective Study-
}

\author{
Nobuo Wakata, Hiroshi Nemoto, Shinngo Konno, Hiroshi Nakazora, Nobuatsu Nomoto, \\ Hideki Sugimoto and Teruyuki Kurihara
}

\begin{abstract}
Background The most common treatment of myasthenia gravis is high-dose prednisolone administration and thymectomy. A well-known adverse effect of prednisolone is hyperglycemia, however, to date there is no such detailed report.

Patients and Methods We treated 325 myasthenia gravis patients in a recent 35 years period, and found 11 patients with diabetes mellitus. We compared these 11 diabetic patients with previously-reported cases.

Results These 11 patients did not have any antibody against $\beta$-cells in the pancreas such as anti-glutamic acid decarboxylase antibody. In 10 of 11 patients diabetes mellitus was controlled with oral medications.

Conclusion Myasthenic patients with diabetes mellitus could be classified into 2 groups, one group with positive organ-specific autoantibodies to many organs (with type 1 diabetes mellitus), and the other group with diabetes mellitus onset during prednisolone administration (with type 2 diabetes mellitus).
\end{abstract}

Key words: myasthenia gravis, diabetes mellitus, anti-GAD antibody, anti-islet cell antibody, IDDM, NIDDM

(DOI: 10.2169/internalmedicine.46.6237)

\section{Introduction}

Myasthenia gravis (MG) is an autoimmune disease which is believed to occur when anti-acetylcholine receptor (AChR) antibody binds to the post synaptic receptor site. Some cases of diabetes mellitus (DM) are also thought to result from an autoimmune mechanism against $\beta$-cells in the pancreas such as anti-glutamic acid decarboxylase (GAD) antibody and/or anti-islet cell antibody in insulin-dependent diabetes mellitus (type $1 \mathrm{DM})$. In one report on neuromuscular disease, anti-GAD antibody was also positive in certain diseases. It is well known that $40-60 \%$ of Stiff person syndrome cases have positive anti-GAD antibody (1), and that this antibody was present in MG-associated DM patients (2-5). One of the most important therapeutic strategies for $\mathrm{MG}$ is high doses prednisolone administration, though subsequent hyperglycemia is a common adverse effect of prednisolone. We examined whether prednisolone induced hyperglycemia in patients predisposed to DM or whether an autoimmune mechanism was responsible.

\section{Patients}

We treated 325 cases of MG from 1968-2004 and encountered 11 cases of DM. Eight male (60-93 years old) and 3 female (64-74 years old) patients were examined, and 7 patients underwent thymectomy. They included 6 hyperplasia and 1 invasive thymoma cases. MG was diagnosed on the basis of typical history and clinical signs, positive responses to i.v. edrophonium chloride, electromyographic examination ( $>20 \%$ decrement at the 4 th stimulus on repetitive nerve stimulation test) and positive value for anti-AChR antibody titer $(>0.2 \mathrm{nmol} / \mathrm{l})$. Three cases of sero-negative MG were found (anti-muscle specific tyrosine kinase antibody was not examined), and they were diagnosed on the basis of typical clinical signs, positive edrophonium chloride test or positive waning phenomenon by repetitive nerve stimulation test. DM was defined as over $126 \mathrm{mg} / \mathrm{dl}$ fasting blood sugar and over $200 \mathrm{mg} / \mathrm{dl}$ blood sugar 2 hours after $75 \mathrm{~g}$ oral glucose tolerance test. We studied clinical datum such as MG classification, thymus pathology, dose of PSL and DM treat- 
Table 1. Summary of Patients

\begin{tabular}{|c|c|c|c|c|c|c|c|c|c|}
\hline $\begin{array}{c}\text { Case } \\
\text { Age/gender }\end{array}$ & $\begin{array}{l}\text { MGFA } \\
\text { classificati } \\
\text { Onset/preser }\end{array}$ & $\begin{array}{l}\text { Thymus finding } \\
\text { ion } \\
\text { nt }\end{array}$ & $\begin{array}{l}\text { Prednisolone } \\
\text { Max/present/period } \\
\text { (alternate day) }\end{array}$ & $\begin{array}{l}\text { DM onset } \\
\text { after MG onse }\end{array}$ & $\begin{array}{l}\text { DM therapy } \\
\text { set }\end{array}$ & $\begin{array}{l}\mathrm{HbA1c} \\
(<5.8) \\
\text { (FBS) }\end{array}$ & $\begin{array}{l}\text { C-peptide } \\
(0.7 \sim 2.2)\end{array}$ & $\begin{array}{c}\text { Anti-GAD ab } \\
(<1.5)\end{array}$ & $\begin{array}{c}\text { Anti-ACh R ab } \\
\text { onset/present } \\
(<0.2 \mathrm{nmol} / \mathrm{l})\end{array}$ \\
\hline 1. $63 / \mathrm{M}$ & $\mathrm{III} / 0$ & hyperplasia & $100 \mathrm{mg} / 0 \mathrm{mg} / 6 \mathrm{Y}$ & $4 \mathrm{Y}$ & $\begin{array}{l}\text { Glibenclamide } 5 \mathrm{mg} \\
\text { Nateglinide } 30 \mathrm{mg}\end{array}$ & $\begin{array}{l}\text { g } 6.7 \\
(133)\end{array}$ & 4.3 & 0.4 & $0.2 / 0.2$ \\
\hline 2. $64 / \mathrm{M}$ & IIa/I & hyperplasia & $100 / 24 / 6 Y$ & $3 \mathrm{Y}$ & diet & $\begin{array}{c}7.6 \\
(216)\end{array}$ & 4.8 & 0.3 & $1.4 / 0.4$ \\
\hline 3. $60 / \mathrm{M}$ & $\mathrm{III} / 0$ & hyperplasia & $100 / 10 / 5 Y$ & $2 \mathrm{Y}$ & diet & $\begin{array}{l}5.9 \\
(129)\end{array}$ & 2.0 & 0.3 & $1.5 / 0.2$ \\
\hline 4. $54 / \mathrm{M}$ & $\mathrm{Vb} / \mathrm{IIa}$ & $\begin{array}{r}\text { invasive } \\
\text { thymoma }\end{array}$ & $140 / 60 / 5 \mathrm{Y}$ & $4 \mathrm{M}$ & $\begin{array}{l}\text { Glibenclamide } 10 \mathrm{mg} \\
\text { Voglibose } 0.9 \mathrm{mg}\end{array}$ & $\begin{array}{l}5.9 \\
(117)\end{array}$ & 2.7 & 0.3 & $41 / 30$ \\
\hline 5. $63 / \mathrm{M}$ & $\mathrm{IIIb} / 0$ & hyperplasia & $80 / 8 / 12 Y$ & $30 \mathrm{Y}$ & diet & $\begin{array}{c}6.6 \\
(131)\end{array}$ & 3.4 & 0.3 & $8 / 0.8$ \\
\hline 6. $67 / \mathrm{M}$ & $\mathrm{I} / 0$ & hyperplasia & $100 / 21 / 1.5 Y$ & $3 \mathrm{M}$ & $\begin{array}{l}\text { Voglibose } 0.9 \mathrm{mg} \\
\text { Nateglimide } 270 \mathrm{mg}\end{array}$ & $\begin{array}{l}8.1 \\
(136)\end{array}$ & 2.6 & 0.3 & $2.2 / 2.1$ \\
\hline 7. $62 / \mathrm{M}$ & $\Pi \mathrm{II} / \mathrm{I}$ & hyperplasia & $100 / 0 / 3.6 \mathrm{Y}$ & $15 \mathrm{Y}$ & diet & $\begin{array}{l}5.8 \\
(101)\end{array}$ & 3.2 & 0.3 & $92 / 580$ \\
\hline 8. $74 / \mathrm{F}$ & IIIa/0 & n.e. & $60 / 0 / 1 Y$ & $-6 Y$ & Penfill-30R 22U & $\begin{array}{l}9.6 \\
(218)\end{array}$ & 1.0 & 0.3 & $0.2 / 0.2$ \\
\hline $9.66 / \mathrm{F}$ & $\mathrm{II} / \mathrm{a} / 0$ & n.e. & $60 / 22.5 / 15 \mathrm{Y}$ & $2 \mathrm{M}$ & $\begin{array}{l}\text { Glibenclamide } 10 \mathrm{mg} \\
\text { Acarbose } 200 \mathrm{mg}\end{array}$ & ag 7.8 & 2.0 & 0.3 & $230 / 380$ \\
\hline $10.64 / \mathrm{F}$ & IIIa/IIa & n.e. & $30 / 10 / 15 Y$ & $25 \mathrm{Y}$ & diet & $\begin{array}{l}5.2 \\
(72)\end{array}$ & 4.9 & 0.3 & $0.2 / 0.2$ \\
\hline 11. 93/M & $\mathrm{III} / \mathrm{I}$ & n.e. & $60 / 5 / 10 Y$ & $8 \mathrm{Y}$ & diet & $\begin{array}{l}6.7 \\
(111)\end{array}$ & 6.8 & 0.3 & $87.8 / 37$ \\
\hline
\end{tabular}

MGFA: myasthenia gravis foundation of America, Max.: maximum, DM: Diabetus mellitus, FBS: fasting blood sugar, HbAlc: hemoglobin A1c, Anti-AChR ab: anti-acetylcholine reptor antibody, Anti-GAD ab: anti-glutamic acid decarboxylase antibody, Y: year, M: month, n.e.: not examined, U: unit.

ment, and defined high-dose PSL as up to $1 \mathrm{mg} / \mathrm{kg}$ body weight on alternate-days. Then we measured $\mathrm{HbA}_{\mathrm{c}}, \mathrm{C}$ protein, anti-GAD antibody and anti-AChR antibody.

\section{Results}

The male/female ratio was $8: 3$, and male was predominant. There was no significant difference between MG type (MGFA classification) and DM severity. There was also no significant difference between thymectomy, thymus pathology and DM occurrence. High-dose prednisolone was administered, except in case 10. DM started during prednisolone administration in 9 cases, but case 7 started 10 years and case 8, 7 years, after prednisolone withdrawal. Injected insulin was administered to cases 4 and 8 . Case 4 started prednisolone before thymectomy because of symptom severity. He suffered a post-thymectomy crisis, after which insulin was injected, but he was subsequently controlled with glibenclamide and voglibose. Case 8, who had DM before MG onset, was controlled with glibenclamide; however, after that she was later given injected insulin because she could not maintain diet therapy. The other patients were controlled with diet and oral medication. DM control was relatively satisfactory but 4 patients had $\mathrm{HbA}_{1 \mathrm{c}}$ of over $7.0 \%$. Serum C-peptide was normal or high. All patients were negative for anti-GAD antibody. Anti-AChR antibody was negative in 3 patients throughout the observation period, and became sero-negative in 1 patient (Table 1).

\section{Discussion}

DM prevalence varies greatly by nationality. The gender prevalence was reported to be $7.1 \%$ in males and $4.5 \%$ in females in Japan (6). There appears to be no detailed preva- lence reports on the association of MG and DM, but it has been calculated to be $2-3 \%$ (7). The prevalence in our patients was $3.4 \%$, lower than in the general population. Because MG patients are sometimes checked for their blood sugar level, they subsequently may pay careful attention to their food intake. There are reports of MG accompanied by DM associated with primary biliary cirrhosis (8), pernicious anemia, autoimmune thyroiditis and autoimmune adrenalitis (9), juvenile chronic arthritis (10), and positive autoantibody for islet cells, gastric mucosa and thyroid gland (11). Among MG patients accompanied by DM and anti-GAD antibody; additional complications included thymoma (3), Stiff person syndrome and Hashimoto's thyroiditis (3), thymoma, autoimmune hepatitis and Hashimoto's thyroiditis (4) and one patient who suffered type $2 \mathrm{DM}$, who was given interleukin-2 because of renal cell carcinoma, developed myositis and type 1 DM (6). All patients were given injected insulin. The former 4 cases may include the latter group, because they were reported before 1990 and, at that time anti-GAD antibody analysis was not common (Table 2).

The present study included 8 males and 3 females, which is an unusual finding as MG prevalence is higher in females. C-peptide has been the most important research tool in the study of the natural course of $\beta$-cell destruction in type 1 DM patients (12). Most patients showed normal or high $C$ peptide levels, meaning their $\beta$-cell function was maintained. Anti-GAD antibody was negative in all patients, and their DM onset was not a result of an autoimmune mechanism.

Corticosteroid-induced hyperglycemia or DM is thought to occur because corticosteroid acts on post insulin-receptor mechanisms to induce dose-dependent insensitivity of insulin's target tissues. Dosages equivalent to $30 \mathrm{mg} / \mathrm{day}$ or more of prednisolone are particularly likely to raise glucose 
Table 2. Myasthenia Gravis and Diabetes Mellitus Associated with Another Autoimmune Disorders

\begin{tabular}{|c|c|c|c|c|c|c|c|c|c|c|}
\hline & MG & DM & Thymoma & $\begin{array}{l}\text { Stiff person } \\
\text { syndrome }\end{array}$ & $\begin{array}{l}\text { Hashimoto } \\
\text { thyroiditis }\end{array}$ & $\begin{array}{l}\text { Autoimmune } \\
\text { hepatitis }\end{array}$ & $\begin{array}{l}\text { Pernicious } \\
\text { anemia }\end{array}$ & Anti-GAD ab & Anti-IC & ab Othters \\
\hline $\begin{array}{l}\text { Taillan } \\
1989\end{array}$ & + & + & - & - & - & - & - & n.e. & n.e. & PBC \\
\hline $\begin{array}{l}\text { Green } \\
1988\end{array}$ & + & + & - & - & + & - & + & n.e. & n.e & $\begin{array}{l}\text { autoimmune } \\
\text { adrenalitis }\end{array}$ \\
\hline $\begin{array}{l}\text { Jenkins } \\
1989\end{array}$ & + & + & - & - & - & - & - & n.e. & n.e. & arthritis \\
\hline $\begin{array}{l}\text { Paolisso } \\
1990\end{array}$ & + & + & - & - & - & - & - & n.e. & n.e. & \\
\hline $\begin{array}{l}\text { Aso } \\
1997\end{array}$ & + & + & - & + & + & - & - & + & + & \\
\hline $\begin{array}{l}\text { Kitae } \\
2001\end{array}$ & + & + & + & + & - & - & - & + & + & \\
\hline $\begin{array}{l}\text { Asakawa } \\
2002\end{array}$ & + & + & $\stackrel{+}{+}$ & - & + & + & - & + & + & \\
\hline $\begin{array}{l}\text { Fraenkel } \\
2002\end{array}$ & + & + & - & - & - & - & - & + & n.e & $\begin{array}{c}\text { renal cancer, } \\
\text { myositis }\end{array}$ \\
\hline
\end{tabular}

MG: myasthenia gravis, DM: diabetes mellitus, Anti-GAD ab: anti-glutamic acid decarboxylase antibody, Anti-IC ab: anti-islet cell antibody, PBC: primary biliary cirrhosis, n.e.: not examined

levels in diabetic patients, and can induce glucose intolerance or diabetes in previously normoglycemic subjects (13).

These findings suggest that MG-associated DM can be classified into 2 groups: 1) those that sometimes have accompanying thymoma and have positive organ-specific autoantibody to neuro-muscular junction (anti-AChR antibody), pancreas $\beta$-cell (anti-GAD antibody and anti-islet cell antibody), thyroid (antithyroglobin antibody, antithyroid peroxidase antibody), liver (histological findings) and stomach (antibodies to gastric parietal cells). 2) the so-called type 2
DM patients; DM appears during prednisolone administration, with evidence of hyperglycemia or DM.

In the present study, 9 out of 11 patients with MG developed DM during prednisolone administration, however, 3 patients remained diabetic after prednisolone withdrawal and 2 patients had DM onset 7-10 years after prednisolone withdrawal. Therefore, it remains unclear whether prednisolone administration directly induced DM, or if it merely accelerated disease onset.

\section{References}

1. Vincent A, Grimaldi LME, Martino G, et al. Antibodies to 125Iglutamic acid decarboxylase in patients with stiff man syndrome. J Neurol Neurosurg Psychiatry 62: 395-397, 1997.

2. Kitae S, Kawakami H, Matsuoka N, Etoh R, Nakamura S. A case of myasthenia gravis accompanied by large thymoma and antiGAD antibody. Rinsho Shinkeigaku 41: 818-821, 2001.

3. Aso Y, Sato A, Narimatsu M, et al. Stiff-man syndrome associated with antecedent myasthenia gravis and organ-specific autoimmunopathy. Intern Med 36: 308-311, 1997.

4. Asakawa H, Kashihara T, Fukuda H, Yamamoto M. A patient with thymoma and four different organ-specific autoimmune diseases. Neth J Med 60: 292-295, 2002.

5. Fraenkel PG, Rutkove SB, Matheson JK, et al. Induction of myasthenia gravis, myositis, and insulin-dependent diabetes mellitus by high-dose interleukin-2 in a patient with renal cell cancer. J Immunother 25: 373-378, 2002.

6. Sasaki Y, Tominaga M, Eguchi H, et al. Comparison of the prevalence of diabetes mellitus an impaired glucose tolerance in Japan and other countries. Diabetes 41: 355-362, 1998 (in Japanese).

7. Simpson JA. Immunological disturbances in myasthenia gravis with a report of Hashimoto's disease developing after thymectomy. J Neurol Neurosurg Psychiatry 27: 485-492, 1964.
8. Taillan B, Hastier P, Vinti H, et al. The association of myasthenia gravis, primary biliary cirrhosis and insulin-dependent diabetes. Presse Med 18: 493, 1989 (in French).

9. Green ST, Ng JP, Chan-Lam D. Insulin-dependent diabetes mellitus, myasthenia gravis, pernicious anaemia, autoimmune thyroiditis and autoimmune adrenalitis in single patient. Scot Med J 33: 213-214, 1988.

10. Jenkins EA, Hull RG, Gray RES, et al. Diabetes mellitus and myasthenia gravis in a patient with systemic onset juvenile chronic arthritis. J R Soc Med 82: 368-369, 1989.

11. Paolisso G, Varricchio M, Donofrio F. Thymectomy and azathioprine in the treatment of type 1 (insulin-dependent) diabetes mellitus. Diabete Metab 16: 524-525, 1990.

12. Bennett PH, Knowler WC. Definition, diagnosis, and classification of diabetes mellitus and glucose homeostasis. In: Joslin's Diabetes Mellitus, 14th ed. Kahn CR, Weir GC, King GL, Jacobson AM, Smith RJ, Eds. Lippincott Willians \& Willkins, Philadelphia, 2004: 333-334.

13. Gittoes NJL, Kendall MJ, Ferner RE. Drugs and diabetes mellitus. In: Pickup J, William G, Eds. Textbook of Diabetes. 2nd ed. Bickwell Science, Massachusetts, 1997: 69.1-69.10.

(C) 2007 The Japanese Society of Internal Medicine http://www.naika.or.jp/imindex.html 